\title{
The Moderating Effect of Environmental Innovation on the Relationship between Corporate Social Responsibility and Environmental Performance: Proposal of a Theoretical Model
}

\author{
Mehmet Fatih Burak
}

\section{ABSTRACT}

\begin{abstract}
Today, it becomes indispensable for businesses to have socially responsible behaviors and environmental approaches. Businesses should prioritize corporate social responsibility (CSR), environmental innovation and environmental performance in order to avoid global environmental problems that may emerge as a result of irresponsible behaviours and lack of environmental protection. This study aims to propose a theoretical model for the relationship between CSR, environmental innovation and environmental performance. For this purpose, the relations between the variables were examined in the light of research and studies in the literature and a theoretical model was proposed based on the information obtained.
\end{abstract}

Keywords: Corporate Social Responsibility, Environmental Innovation, Environmental Performance.

\section{INTRODUCTION}

It is becoming increasingly important for businesses to be socially responsible on a day-to-day basis. In a world of rapid changes, problems are now becoming more global, complex and diverse. Issues such as unethical business practices and environmental pollution can attract a lot of reaction from the society. Therefore, businesses have to seek a way to perform sustainable business practices [1]. Businesses that want to succeed and innovate need to take into account the environmental effects and social reflections of their operational activities, encourage their employees to embrace novelties for the development of innovative products and carry out these innovation development processes in solidarity with other stakeholders [2]. Environmental innovation is understood to positively affect environmental performance [3], [4] and financial performance [5], [6], sustainability [7], employment [8], and consumer intention to purchase [9], to contribute to the carbon dioxide emission reduction [10], and to increase businesses' efficiency and productivity performance [11], company attractiveness [12], and corporate reputation [13]. Therefore, the environmental innovations developed with the consideration of CSR may be more successful and these achievements may also positively affect environmental performance.

This study aims to propose a theoretical model for the moderator effect of environmental innovation on the relationship between CSR and environmental performance, which has not been examined before. In this context, the relations between concepts and propositions developed in this study were mentioned based on previous studies in the relevant literature, and a theoretical model was proposed. The conclusion refers to the proposed theoretical model's importance and makes proposals for its implementation.

\section{THEORETICAL REVIEW}

\section{A. Corporate Social Responsibility and Environmental Performance}

CSR involves "a situation in which businesses incorporate actions that create and develop some social benefits beyond their interests and legal requirements imposed on them" [14]. CSR can be effective in helping businesses build a positive image in their environment [15]. It is important to consider CSR as a strategic investment tool and establish strong relations with stakeholders [16]. There are many theories in the literature on CSR. Garriga and Melé explained the CSR theories by dividing them into four categories in their study. These include "instrumental theories," which emphasizes the aim of making a profit, "political theories", which emphasizes political responsibility, "integrative theories", which emphasizes the integration of activities with social demands, and "ethical theories", which emphasizes ethical values [17].

Environmental performance is "the measurable results of managing the environmental aspects of organizations" [18]. Environmental performance indicators include factors affecting the environment such as "pollution, biological diversity, climate, energy, erosion, ecosystem services, environment educations, etc." [19]. Environmental performance can lead to a positive impact on corporate performance and competitiveness, employee health, and an increase in the quality of environmental inputs, etc. [20], [21]. 
An examination of the studies in the literature on the relationship between CSR and environmental and social performance shows that Ikram et al. [22] concluded in their research on 340 small and medium-sized enterprises (SMEs) in Pakistan that CSR's social and environmental aspects have a positive relationship with financial performance, referring to evidence that it can also contribute to the countries' economic growth. While Orazalin [23] stated in his research that businesses with effective CSR strategies can show environmental and social performance better, Shaukat $e t$ al. [24] concluded in their research that CSR strategies positively influence environmental and social performance.

CSR can also be effective on technological innovation and competitive performance [25], [26]. Liu et al. [26] concluded in their research on 277 manufacturing businesses in China that CSR effectively supports the technological innovation performance up to a certain tipping point and that the technological innovation performance will be adversely affected if that point is exceeded. Herrera Madueño et al. [25] concluded in their research on 481 Spanish SMEs that CSR practices enhance competitive performance.

Green credits, state ownership, and earnings management may have a moderating effect on the relationship between CSR and performance [27]-[29]. Zhou et al. [29] concluded in their research on banks in China that corporate social responsibility will adversely affect the banks' financial performance in short term and positively affect it in the long term. Long et al. [27] concluded in their research on Chinese businesses that CSR positively affects financial performance, that state ownership weakens the relationship between CSR and financial performance, and industry competition strengthens the relationship between CSR and financial performance for both state-owned and non-state businesses. Sial et al. [28] found in their research on the listed Chinese companies in Shenzhen and Shanghai stock exchanges that CSR positively affects the business performance, while earnings management has a negative moderating effect between CSR and business performance.

Some other literature studies on the relationship between CSR and performance were examined. Shahzad et al. [30] concluded in a study using unbalanced panel data of publiclytraded companies in the United States from 2009 to 2018 that CSR has a significant effect on the performance of a business, and that intellectual capital productivity has a full mediating effect in the relationship between CSR and business performance. Nguyen et al. [31] stated in their study on 653 managers in large-scale enterprises in Vietnam that ethical leadership positively affects CSR and that it can lead to an increase in business reputation and business performance. Agyemang and Ansong [32] concluded on the basis of research conducted in 423 SMEs in Ghana that businesses with advanced CSR practices are better positioned to achieve enhanced reputations, and thus increase financial performance. Sun and Yu [33] concluded in their research that there is a positive relationship between CSR and employee performance and that businesses with social responsibility had higher labor costs. Yu and Choi [34] concluded in a study on 168 Chinese businesses that perceived CSR practices have a positive effect on employee well-being and corporate performance and that corporate trust has a partial mediation effect on the relationship between perceived CSR practices and corporate performance.

The relationships between CSR and performance can lead to various results in different industries. Feng [35] concluded in their research that the CSR types can have different effects on the financial performance of businesses in different industries. Al-Samman and Al-Nashmi [36], in their study of 103 public and private businesses in Yemen, they concluded that CSR positively affects non-financial corporate performance in state-owned and private businesses. Valmohammadi [37] concluded that CSR practices positively affect corporate performance in their research on 207 Iranian manufacturing and service businesses. Úbeda-García et al. [38] stated that there is a direct and positive relationship between CSR and performance in their research on hotels in Spain, and green human resources management and environmental results have a partial mediation effect between corporate social responsibility and performance. Although it can be determined that CSR positively affects performance in most research [16], [22]-[39], there are studies that concluded CSR negatively affects performance [40], [41] and that there is no significant connection between CSR and performance [42]-[45]. In the light of the research and studies, the first proposition was developed as follows:

Proposition $_{1}$ : CSR is positively related to environmental performance.

\section{B. Corporate Social Responsibility and Environmental Performance: The Moderator Effect of Environmental Innovation}

Environmental innovation is "environmentally focused corporate practices and changes that have an impact on businesses' products, production processes, and marketing with varying degrees of innovation. It can be in the form of gradual improvements or radical improvements" [46]. Environmental innovation can be developed by businesses or non-profit organizations [47].

CSR can positively affect environmental innovation [48][51]. Padilla-Lozano and Collazzo [48] concluded in their research on 325 managers in manufacturing businesses in Ecuador that corporate social responsibility positively affects green innovation, and that green innovation has a partial mediation role between corporate social responsibility and competitiveness. Suganthi [50] also concluded in his study that green practices have a partial mediation effect between CSR and performance. Pan et al. [49] concluded in their research, using data on Chinese businesses obtained from various sources from 2011 to 2015, that environmental CSR is linearly and positively related to pollution prevention innovation, and curvilinearly related to sustainable environmental innovation. Lutao et al. [51] concluded in their research, using data on Chinese businesses obtained from various sources from 2008 to 2014 , that strategic CSR promotes sustainable product innovation, responsive CSR positively affects pollution-preventing product innovation, and that sustainable product innovation has a mediating effect in the relationship between strategic CSR and company performance.

Environmental innovation can positively affect environmental performance [3], [4], [52], [53]. Liao and Zhang [4] concluded in their research on 208 manufacturing 
businesses in China that incremental and radical environmental innovation positively affects the businesses' environmental performance. $\mathrm{Li}$ [52], in his research on 148 manufacturers in China, concluded that environmental innovation practices have significant positive effects on the businesses' environmental performance. Long et al. [3], in their research on 182 Chinese businesses, concluded that environmental innovation behavior has a greater positive effect on environmental performance than economic performance, while Liao et al. [53] concluded that environmental innovation could positively affect businesses' both environmental and financial performance as a result of their meta-analysis.

When other studies in the literature on the relationship between CSR, innovation, and performance are examined; Zahid et al. [54], concluded that CSR activities have a significant positive effect on the determination of financial performance and that competitive advantage and innovation have a mediating effect between CSR activities and financial performance, in their research on 242 manufacturing companies in Pakistan. Bahta et al. [55] concluded in their research on 402 Eritrean SMEs that CSR positively affects financial performance and innovation and that innovation has a partial mediation effect in the relationship between CSR and financial performance. Martinez-Conesa et al. [56] concluded in their study on 552 Spanish businesses that CSR positively affects innovation performance and business performance and that innovation performance has a partial mediation effect in the relationship between CSR and business performance. Reverte et al. [57], concluded in the research conducted on 133 Eco-Responsible Spanish businesses that CSR has a positive effect on both innovation and corporate performance. As such the second proposition, which could not be determined to have been examined in the literature before, was developed as follows:

Proposition $_{2}$ : Environmental innovation positively moderates the relationship between CSR and environmental performance.

The theoretical model developed in line with the propositions in the research is shown in Fig. 1.

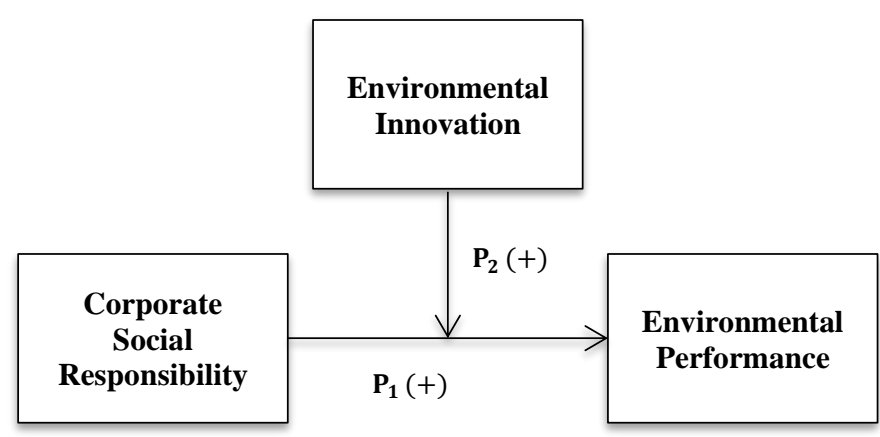

Fig. 1. Theoretical Model.

\section{CONCLUSION}

In the light of the conducted research and studies, businesses can make a profit by achieving environmental performance, etc. not only in the environment but also in their businesses if they carry out their activities with socially responsible and environmentalist approaches. It is important to scientifically explain the gains and effects that can result from socially responsible and environmentalist approaches through scientific research and studies to be carried out as they can motivate business management to acquire this approach accordingly.

This study examines the importance, effects, possible earnings, etc. of CSR, environmental innovation, and environmental performance according to the literature. It is also important that government institutions pave the way for businesses and encourage them as their desire may not be sufficient for them to take these socially responsible and environment-friendly approaches [58], [59].

In this study, the relationships between the variables were questioned, and a theoretical model was proposed by underlining environmental innovation's possible moderator effect in the relationship between corporate social responsibility and environmental performance, which could not be confirmed to be examined in the literature before.

There are validated and reliable measurement tools in the relevant literature to measure variables in the proposed theoretical model. The theoretical model proposed in this study can be tested in different sectors and at different times with empirical studies. Different results are likely to be obtained if future empirical studies are conducted in different industries at different times.

\section{REFERENCES}

[1] G. Rexhepi, S. Kurtishi, and G. Bexheti, "Corporate Socia Responsibility (CSR) and Innovation - The Drivers of Business Growth?," Procedia - Social and Behavioral Sciences, vol. 75, pp. 532541,2013

[2] S. P. MacGregor and J. Fontrodona, "Exploring the fit between CSR and innovation," Working paper 759, IESE Business School, University of Navarra, 2008.

[3] X. Long, et al., "The effect of environmental innovation behavior on economic and environmental performance of 182 Chinese firms," Journal of Cleaner Production, vol. 166, pp. 1274-1282, 2017.

[4] Z. Liao and M. Zhang, "The influence of responsible leadership on environmental innovation and environmental performance: The moderating role of managerial discretion," Corporate Social Responsibility and Environmental Management, vol. 27, no. 5, pp. 2016-2027, 2020.

[5] Z. J. Liao, "Corporate culture, environmental innovation and financial performance," Business Strategy and the Environment, vol. 27, no. 8, pp. 1368-1375, 2018.

[6] S. P. Saeidi, M. S. H. Othman, P. Saeidi, and S. P. Saeidi, "The moderating role of environmental management accounting between environmental innovation and firm financial performance," International Journal of Business Performance Management, vol. 19, no. 3 , pp. 326-348, 2018

[7] P. S. Sanchez-Medina, J. Corbett, and A. Toledo-Lopez, "Environmental Innovation and Sustainability in Small Handicraft Businesses in Mexico," Sustainability, vol. 3, no. 7, pp. 984-1002, 2011.

[8] W. Yu and H. F. Yu, "The Effect of Environmental Innovation on Employment Level: Evidence from China's Manufacturing Industries," Problemy Ekorozwoju, vol. 12, no. 1, pp. 7-14, 2017.

[9] S. Y. Long and Z. J. Liao, "Would consumers pay for environmental innovation? The moderating role of corporate environmental violations," Environmental Science and Pollution Research, vol. 28, no. 23, pp. 29075-29084, 2021.

[10] D. Tobelmann and T. Wendler, "The impact of environmental innovation on carbon dioxide emissions," Journal of Cleaner Production, vol. 244, 2020.

[11] G. C. Wu, "Environmental innovation approaches and business performance: effects of environmental regulations and resource commitment," Innovation-Organization \& Management, vol. 19, no. 4, pp. 407-427, 2017.

[12] Z. J. Liao and J. L. Cheng, "Can a firm's environmental innovation attract job seekers? Evidence from experiments," Corporate Social Responsibility and Environmental Management, vol. 27, no. 2, pp. 542551,2020 . 
[13] Z. J. Liao, "Environmental policy instruments, environmental innovation and the reputation of enterprises," Journal of Cleaner Production, vol. 171, pp. 1111-1117, 2018.

[14] A. McWilliams, D. S. Siegel, and P. M. Wright, "Corporate Social Responsibility: Strategic Implications*," Journal of Management Studies, vol. 43, no. 1, pp. 1-18, 2006.

[15] P. Rodrigues, E. Real, F. Vitorino, and I. Cantista. "The importance of corporate social responsibility in the brand image," in 10th International Marketing Trends Congress, Paris, January. 2011.

[16] D. Devie, L. P. Liman, J. Tarigan, and F. Jie, "Corporate social responsibility, financial performance and risk in Indonesian natural resources industry," Social Responsibility Journal, vol. 16, no. 1, pp. 73-90, 2020.

[17] E. Garriga and D. Melé, "Corporate Social Responsibility Theories: Mapping the Territory," Journal of Business Ethics, vol. 53, no. 1, pp 51-71, 2004.

[18] ISO 14001, "Environmental Management Systems-Requirements with Guidance for Use," International Standards Organization, Geneva, Switzerland, 2015.

[19] D. Ruez, "Environmental Performance Indicators", in Environmental Science, N. Malakar, Ed. The Connexions Project, U of I Open Source Textbook Initiative, 2019, pp. 466-473.

[20] E. Chinomona and M. Mahlatsi, "Green supply chain practices and supply chain performance in the beverage industry of South Africa," Journal of Contemporary Management, vol. 17, no. 2, pp. 295-325, 2020.

[21] L. Lankoski, "Determinants of environmental profit: An analysis of the firm-level relationship between environmental performance and economic performance," Ph.D. dissertations, Helsinki University of Technology, Institute of Strategy and International Business, 2000.

[22] M. Ikram, et al., "Does CSR influence firm performance? A longitudinal study of SME sectors of Pakistan," Journal of Global Responsibility, vol. 11, no. 1, pp. 27-53, 2020.

[23] N. Orazalin, "Do board sustainability committees contribute to corporate environmental and social performance? The mediating role of corporate social responsibility strategy," Business Strategy and the Environment, vol. 29, no. 1, pp. 140-153, 2020.

[24] A. Shaukat, Y. Qiu, and G. Trojanowski, "Board Attributes, Corporate Social Responsibility Strategy, and Corporate Environmental and Social Performance," Journal of Business Ethics, vol. 135, no. 3, pp. $569-585,2016$

[25] J. Herrera Madueño, M. Larrán Jorge, I. Martínez Conesa, and D. Martínez-Martínez, "Relationship between corporate social responsibility and competitive performance in Spanish SMEs: Empirical evidence from a stakeholders' perspective," BRQ Business Research Quarterly, vol. 19, no. 1, pp. 55-72, 2016.

[26] Y. Liu, Y. Chen, Y. Ren, and B. Jin, "Impact mechanism of corporate social responsibility on sustainable technological innovation performance from the perspective of corporate social capital," Journal of Cleaner Production, vol. 308, pp. 127345, 2021.

[27] W. Long, S. Li, H. Wu, and X. Song, "Corporate social responsibility and financial performance: The roles of government intervention and market competition," Corporate Social Responsibility and Environmental Management, vol. 27, no. 2, pp. 525-541, 2020.

[28] M. S. Sial, Z. Chunmei, T. Khan, and V. K. Nguyen, "Corporate social responsibility, firm performance and the moderating effect of earnings management in Chinese firms," Asia-Pacific Journal of Business Administration, vol. 10, no. 2/3, pp. 184-199, 2018.

[29] G. Zhou, Y. Sun, S. Luo, and J. Liao, "Corporate social responsibility and bank financial performance in China: The moderating role of green credit," Energy Economics, vol. 97, pp. 105190, 2021.

[30] F. Shahzad, M. H. Baig, I. U. Rehman, A. Saeed, and G. A. Asim, "Does intellectual capital efficiency explain corporate social responsibility engagement-firm performance relationship? Evidence from environmental, social and governance performance of US listed firms," Borsa Istanbul Review, 2021.

[31] N. T. T. Nguyen, N. P. Nguyen, and T. Thanh Hoai, "Ethical leadership, corporate social responsibility, firm reputation, and firm performance: A serial mediation model," Heliyon, vol. 7, no. 4, pp. e06809, 2021.

[32] O. S. Agyemang and A. Ansong, "Corporate social responsibility and firm performance of Ghanaian SMEs," Journal of Global Responsibility, vol. 8, no. 1, pp. 47-62, 2017.

[33] L. Sun and T.R. Yu, "The impact of corporate social responsibility on employee performance and cost," Review of Accounting and Finance, vol. 14, no. 3, pp. 262-284, 2015.

[34] Y. Yu and Y. Choi, "Corporate social responsibility and firm performance through the mediating effect of organizational trust in Chinese firms," Chinese Management Studies, vol. 8, no. 4, pp. 577$592,2014$.
[35] M. Feng, X. Wang, and J. G. Kreuze, "Corporate social responsibility and firm financial performance," American Journal of Business, vol. 32, no. 3-4, pp. 106-133, 2017.

[36] E. Al-Samman and M. M. Al-Nashmi, "Effect of corporate social responsibility on nonfinancial organizational performance: evidence from Yemeni for-profit public and private enterprises," Social Responsibility Journal, vol. 12, no. 2, pp. 247-262, 2016

[37] C. Valmohammadi, "Impact of corporate social responsibility practices on organizational performance: an ISO 26000 perspective," Social Responsibility Journal, vol. 10, no. 3, pp. 455-479, 2014.

[38] M. Úbeda-García, E. Claver-Cortés, B. Marco-Lajara, and P. ZaragozaSáez, "Corporate social responsibility and firm performance in the hotel industry. The mediating role of green human resource management and environmental outcomes," Journal of Business Research, vol. 123, pp. 57-69, 2021.

[39] K. Singh and M. Misra, "Linking Corporate Social Responsibility (CSR) and Organizational Performance: the moderating effect of corporate reputation," European Research on Management and Business Economics, vol. 27, no. 1, pp. 100139, 2021.

[40] W. Han, Y. Zhuangxiong, and L. Jie, "Corporate social responsibility, product market competition, and product market performance," International Review of Economics \& Finance, vol. 56, pp. 75-91, 2018.

[41] N. Ngoc, "The Effect of Corporate Social Responsibility Disclosure on Financial Performance: Evidence from Credit Institutions in Vietnam," Asian Social Science, vol. 14, no. 4, pp. 109-122, 2018.

[42] V. Lima Crisóstomo, F. de Souza Freire, and F. Cortes de Vasconcellos, "Corporate social responsibility, firm value and financial performance in Brazil," Social Responsibility Journal, vol. 7, no. 2, pp 295-309, 2011

[43] W. L. Lin, J. A. Ho, S. I. Ng, and C. Lee, "Does corporate social responsibility lead to improved firm performance? The hidden role of financial slack," Social Responsibility Journal, vol. 16, no. 7, pp. 957982, 2020.

[44] A. McWilliams and D. Siegel, "Corporate social responsibility and financial performance: correlation or misspecification?," Strategic Management Journal, vol. 21, no. 5, pp. 603-609, 2000

[45] J. Surroca, J. A. Tribó, and S. Waddock, "Corporate responsibility and financial performance: the role of intangible resources," Strategic Management Journal, vol. 31, no. 5, pp. 463-490, 2010

[46] F. Dias Angelo, C. Jose Chiappetta Jabbour, and S. Vasconcellos Galina, "Environmental innovation: in search of a meaning," World Journal of Entrepreneurship, Management and Sustainable Development, vol. 8, no. 2/3, pp. 113-121, 2012.

[47] K. Rennings, "Redefining innovation - eco-innovation research and the contribution from ecological economics," Ecological Economics, vol. 32, no. 2, pp. 319-332, 2000.

[48] C. P. Padilla-Lozano and P. Collazzo, "Corporate social responsibility, green innovation and competitiveness - causality in manufacturing," Competitiveness Review: An International Business Journal, vol. ahead-of-print, no.ahead-of-print, 2021.

[49] X. Pan, P. Sinha, and X. Chen, "Corporate social responsibility and eco-innovation: The triple bottom line perspective," Corporate Social Responsibility and Environmental Management, vol. 28, no. 1, pp. 214 228, 2021.

[50] L. Suganthi, "Examining the relationship between corporate social responsibility, performance, employees' pro-environmental behavior at work with green practices as mediator," Journal of Cleaner Production, vol. 232, pp. 739-750, 2019.

[51] N. Lutao, P. Xin, and X. Xuhong. "Corporate social responsibility, environmental product innovation and firm performance: Evidence from Chinese listed firms," in 2017 IEEE Technology \& Engineering Management Conference (TEMSCON), 2017

[52] Y. Li, "Environmental innovation practices and performance: moderating effect of resource commitment," Journal of Cleaner Production, vol. 66, pp. 450-458, 2014.

[53] Z. Liao, P. Liu, and S. Liu, "A meta-analysis of environmental innovation and firm performance," Journal of Environmental Planning and Management, vol. 64, no. 11, pp. 2047-2065, 2021.

[54] M. Zahid, H. Naeem, I. Aftab, and S. A. Mughal, "From corporate social responsibility activities to financial performance: role of innovation and competitive advantage," Asia Pacific Journal of Innovation and Entrepreneurship, vol. 15, no. 1, pp. 2-13, 2021

[55] D. Bahta, J. Yun, M. R. Islam, and M. Ashfaq, "Corporate social responsibility, innovation capability and firm performance: evidence from SME," Social Responsibility Journal, vol. ahead-of-print, no.ahead-of-print, 2020.

[56] I. Martinez-Conesa, P. Soto-Acosta, and M. Palacios-Manzano, "Corporate social responsibility and its effect on innovation and firm 
performance: An empirical research in SMEs," Journal of Cleaner Production, vol. 142, pp. 2374-2383, 2017.

[57] C. Reverte, E. Gómez-Melero, and J. G. Cegarra-Navarro, "The influence of corporate social responsibility practices on organizational performance: evidence from Eco-Responsible Spanish firms," Journal of Cleaner Production, vol. 112, pp. 2870-2884, 2016.

[58] J.-P. Gond, N. Kang, and J. Moon, "The government of self-regulation: on the comparative dynamics of corporate social responsibility," Economy and Society, vol. 40, no. 4, pp. 640-671, 2011.

[59] G. Ö. Wingqvist, O. Drakenberg, D. Slunge, M. Sjöstedt, and A. Ekbom, "The role of governance for improved environmental outcomes: Perspectives for developing countries and countries in transition," Swedish Environmental Protection Agency, Report 6514. Naturvårdsverket, 2012. 